\title{
REFLECTIONS ON THE CIVIL WAR IN NEW JERSEY: MEN, WOMEN, AND ARCHIVES
}

\section{BY FERNANDA H. PERRONE}

\section{Introduction and Acknowledgments}

This special issue of The Journal of the Rutgers University Libraries (JRUL) commemorates the one hundred and fiftieth anniversary of the American Civil War (1861-1865) in the state of New Jersey. Although the battlefields were miles from its borders, the bitter struggles of the Civil War had a profound effect on New Jersey, which supplied over 88,000 men to the Union armies, and was represented in every major battle. 6,082 enlisted men and 218 officers lost their lives in the course of the war. ${ }^{1}$ The thousands of New Jersey men wounded in the war suffered untold physical, psychological, and economic hardships in the years ahead. On the home front, women, children, and the elderly struggled to keep farms, businesses, and schools afloat in the absence of husbands, sons, and fathers. Women played an important role in supporting the war, both at home and on the battlefield, despite the constrictions of gender roles of the time. While New Jersey African Americans welcomed the fight to abolish slavery, their role in the conflict was also limited by the racist structures and beliefs of their society. The authors who have contributed to this special issue of the JRUL will explore all of these issues.

This sesquicentennial period (2011-2015) has reignited interest in the Civil War, resulting in numerous publications, exhibitions, and public programs throughout the state, particularly through the efforts of the New Jersey Civil War Sesquicentennial Committee. Special Collections and University Archives of Rutgers University Libraries (SC/UA) sponsored a major exhibition, Struggle Without End: New Jersey and the Civil War, and a series of programs, which were generously supported by the New Jersey Council for the Humanities, a state partner of the National Endowment for the Humanities. Several of the program presenters are contributors

http://dx.doi.org/10.14713/irul.v66i0.1860

Journal of the Rutgers University Libraries, Volume 66, pp.1-21. 
to this volume. The exhibition lives on in digital format at http:// www.libraries.rutgers.edu/rul/exhibits/struggle without end/. I would like to express my sincere thanks to Dr. Robert G. Sewell, the editor of the JRUL, for giving me the opportunity to serve as guest editor and for his support throughout the process. Special thanks go to my colleague Caryn Radick, associate editor of the JRUL, for her skilled editing and for taking on some tedious formatting tasks in the design of this issue. Ken Kuehl from the Rutgers University Libraries administration and the staff of the Scholarly Communication Center, who were responsible for the production of the print and online versions of this issue, are also owed my sincere thanks. Finally, I would like to thank contributors James M. McPherson, Katherine Fleming, Larry A. Greene, and Steven D. Glazer for graciously volunteering their time and expertise to make this publication a reality. Dr. Patricia A. Palmieri gave a fascinating presentation on New Jersey women and the Civil War as part of the exhibition programming, but was unable to contribute an article because of other writing obligations. I am indebted to her scholarship and analysis for my own comments on women and the Civil War in the latter part of this article. Dr. Sandra W. Moss also made many helpful suggestions based on her own research on the history of medicine in New Jersey.

In this article, I will briefly review the existing scholarship on New Jersey and the Civil War, and highlight topics that could be further explored. The essays in this volume, which use $\mathrm{SC} / \mathrm{UA}$ 's collections as well as other resources, will be introduced as examples of new scholarship in this area. Next, I will review SC/UA's resources on the Civil War and New Jersey, and suggest collections that would reward further study. Among these are many resources related to my own area of specialization, the history of women. I will conclude by showing how studying the role of women and gender in New Jersey can contribute to a greater understanding of the history of American women during this tumultuous period.

\section{Historiography of the Civil War in New Jersey}

The Civil War is a vast subject that has produced and continues to produce a wealth of scholarship. Originally the exclusive domain of political and military historians, the conflict has now been studied from social, cultural, medical, and literary perspectives. The literature on the Civil War in New Jersey is in 
itself substantial. Until recent years, however, military and political accounts of the war predominated, such as William J. Jackson's standard New Jerseyans in the Civil War (2000); Joseph G. Bilby's Remember You Are Jerseymen (1998); and Rutgers history professor William Gillette's Jersey Blue: Civil War Politics in New Jersey (1995), which successfully put to rest the argument that New Jersey was a Copperhead state. ${ }^{2}$ Local historian Alan A. Siegel has analyzed the noisy and complicated discourse produced by New Jersey's myriad newspapers during the Civil War period, as well as the battlefield experience of soldiers. ${ }^{3}$ The diversity of the New Jersey military experience has also been explored in histories of individual regiments and localities. ${ }^{4}$ With the advent of the sesquicentennial, the New Jersey Civil War Heritage Association produced two compilations that focus on the social history of the war, New Jersey's Civil War Odyssey and New Jersey Goes to War. ${ }^{5}$ Most recently, Valerie M. Josephson's Stirring Times: The Lives of New Jersey's First Civil War Surgeons (Privately Published, 2013) profiles nine New Jersey surgeons who operated on the battlefield, contributing to the growing literature on the medical history of the Civil War in New Jersey.

\section{About the Articles}

The essays in this volume make an important contribution to the history of the Civil War in New Jersey, promoting a more nuanced and inclusive view of the experience of both combatants and civilians, and a deeper knowledge of the social, medical, and religious history of the war in the state. The authors have used SC/UA's Civil War collections-both manuscript and printedin their research, as well as the resources of the New Jersey State Archives and other New Jersey repositories. Their contributions also suggest how these resources can be further explored by future researchers.

James M. McPherson's "Why the Civil War Still Matters" introduces this volume. McPherson, one of the country's leading Civil War historians, is an emeritus professor at Princeton University. Dr. McPherson graciously allowed us to publish this version of the lecture he delivered at the opening of the Struggle Without End exhibition on September 19, 2012. In answering the question of why a conflict 150 years ago is still important today, McPherson persuasively demonstrates how the issues raised by the Civil War-matters of race and citizenship; regional rivalries; the relative powers and responsibilities of federal, state, and local 
government; and the multiple meanings of the concept of libertyremain fundamental issues in American society. McPherson's wide-ranging and thought-provoking article sets the stage for the exploration of specific questions by the other contributors.

Using New Jersey as a case study, Professor Larry A. Greene of Seton Hall University contributes to the debate over Lincoln as the "Great Emancipator." Taking Steven Spielberg's feature film, Lincoln (2012), which chronicles the effort to pass the Thirteenth Amendment through the U.S. Congress in early 1865 as a point of departure, Professor Greene uses the metaphor of "struggle without end" to characterize the long road to freedom for African Americans. Greene's thesis is that the complexity, conservatism, and capacity for growth of Lincoln's perceptions of race mirror those of the nation, the North, and New Jersey in particular. In his analysis of Civil War New Jersey, Professor Greene locates race and African Americans at the center of the conversation rather than at its periphery. He traces attitudes towards race from the colonization movement, which had its roots in New Jersey, to the pronouncements of New Jersey's Civil War-era governors, to the failure of the state to ratify the Thirteenth Amendment in 1865. Greene bases his nuanced and provocative discussion on contemporary newspapers, pamphlets, and other printed sources, most of which are available at SC/UA.

Katherine Fleming's article, "Living Casualties of War: Civil War Soldiers as Victims of Psychological Trauma" is based on her Seton Hall University M.A. thesis, which was completed under Professor Greene's direction. While most historians now accept that some Civil War soldiers suffered from mental illness, the causes and trajectory of that suffering and its interpretation by contemporaries are still a matter of debate. Ms. Fleming is influenced by the work of historians Eric T. Dean and Lisa A. Long, who both argue that Civil War veterans suffered from a form of post-traumatic stress disorder, but disagree over when these symptoms were discovered and how they were understood. ${ }^{6}$ Mining little-used records at the New Jersey State Archives, Fleming tests these arguments against the documented experience of hospitalized New Jersey soldiers. While her conclusions are intriguing, Fleming acknowledges that diaries and letters of combatants, doctors, and nurses, as well as hospital records from other states, need to be explored before these debates can be resolved. Fleming hopes that further research and analysis will help her Civil War soldiers finally rest in peace. 
SC/UA continues to acquire diaries, letters, photographs, and other documentation of Civil War solders and civilians, which may help to answer the questions raised by Fleming, Greene, and others. In 2014, SC/UA received a small collection documenting the short life of Lambertville schoolmaster and sometime store clerk Israel F. Silvers (1832-1864), who served as a delegate with the United States Christian Commission at Gettysburg and in Virginia. SC/UA already holds the Christian Commission diaries of Theodore Sandford Doolittle (1836-1893), a Reformed Church pastor from Brooklyn, who joined the Rutgers College faculty in 1864; and that of Augustus Craven Barber (1819-1901), also of Lambertville, who left the front in Virginia just before Silvers' arrival. As well as conducting religious services and distributing tracts, U.S. Christian Commission delegates wrote letters for soldiers, prepared special meals, distributed supplies, and worked closely with doctors and nurses on the battlefield. I hope that my short piece will encourage other researchers to explore the role of the Christian Commission in the Civil War.

Finally, in "Rutgers in the Civil War," Steven D. Glazer produces a definitive accounting of the Rutgers alumni who served in the Civil War. His meticulous research yields a total considerably higher than the often-cited figure provided by Richard P. McCormick in Rutgers: A Bicentennial History (1966). Most, but not all of Glazer's alumni fought with the Union, unlike at Princeton University, where a considerable number of students from the South returned home to fight for the Confederacy. Glazer points out the inaccuracies of the bronze tablet in the university's Kirkpatrick Chapel honoring the Rutgers men who fought for the Union. The story of the tablet draws attention to the question of how the Civil War has been and continues to live in memory, a debate as relevant in New Jersey as elsewhere.

\section{The Collections}

As well as showcasing recent scholarship on the Civil War in New Jersey, this special issue seeks to draw readers' attention to the rich resources held by Special Collections and University Archives that document the Civil War in New Jersey. SC/UA has one of the largest collections of Civil War manuscripts and publications in the state, including thousands of individual items. The collection complements the holdings of official documents at the New Jersey State Archives, the individual and family papers at the New Jersey 
Historical Society, and numerous collections at local repositories throughout the state. The breadth and depth of Rutgers' collection would be overwhelming, were it not for the guides compiled by the late Donald A. Sinclair, founding curator of SC/UA. Sinclair's masterful A Guide to New Jersey and Other Civil War Manuscripts (New Brunswick, NJ: Rutgers University Libraries, 2003), not only includes bibliographic detail on each and every manuscript with any bearing on the Civil War, but also offers numerous transcriptions of highlights from the most important diaries, letters, and documents, all of which are meticulously indexed. This invaluable guide reveals gems hidden in larger bodies of records, such as that amassed by local historian Charles A. Philhower. Since 2003, Rutgers' Civil War-related holdings have continued to grow through gifts and purchases. These more recent acquisitions can be located in the Rutgers University Libraries online catalog. An earlier volume, also compiled by Donald A. Sinclair, A Bibliography: The Civil War and New Jersey (New Brunswick, NJ: Friends of the Rutgers University Library, 1968), was a late contribution honoring the centennial of the Civil War. This work describes and indexes printed material at the New Jersey State Library, New Jersey Historical Society, Princeton University Libraries, and other repositories in addition to Rutgers. It is still very useful for discovering uncataloged broadsides, pamphlets, ephemera, and other Civil War grey literature. The archives of Rutgers University are also a rich source of information about the Civil War. As well as the papers of alumni, many of which are described in the Civil War manuscripts guide, the Rutgers University Alumni Biographical Files mined by Steven D. Glazer provide documentation of almost every Rutgers man who fought in the war-whether for the Union or the Confederacy. 
The greatest strengths of the Rutgers collection are documentation of the experience of soldiers on the battlefield and the complicated political situation in the state during the war. Probably the most famous collection is that of Washington Roebling of Trenton (1837-1926), builder of the Brooklyn Bridge. During the war, Roebling built suspension bridges, made maps, and did reconnaissance from a hot-air balloon. He saw action at the battles of Second Bull Run, Antietam, Chancellorsville, and Gettysburg, where he helped to secure Little Round Top, as well as the Battle of the Wilderness, Spotsylvania Court House, and the Crater. He was ultimately commissioned Colonel, U.S. Volunteers, by brevet, for "gallant meritorious services during the war." As well as correspondence with his wife Emily and father, engineer John A. Roebling, the collection includes Roebling's wartime sketches of bridges and annotated maps of the Battle of Gettysburg. Another highlight is the collection of Robert McAllister (1813-1891) of Warren County, who participated in practically all of the pitched battles of the Army of the Potomac, first as a lieutenant-colonel in the First New Jersey Volunteers and ultimately as commander of the Second New Jersey Brigade. His collection includes richly-detailed correspondence with his wife and two daughters, photographs, and artifacts. Also noteworthy are the papers and artifacts belonging to Ellis Hamilton of Camden (1845-1864), who, at the age of sixteen became the youngest officer to be commissioned in the Union army.

Rutgers holds papers of all of New Jersey's Civil War-era governors, including Charles S. Olden (1859-1863), Joel Parker (1863-1866), and Marcus L. Ward (1866-1868), as well as those of politicians like the notorious Peace Democrat James W. Wall of Burlington. Among the accounts of soldiers are diaries and letters of battlefield doctors like Princeton graduate Joseph A. Freeman of Orange (1833-1864), assistant surgeon to the Thirteenth Regiment, who gave detailed descriptions of the conditions at Gettysburg-he later died of pneumonia in December 1864. Rutgers alumnus Henry F. Van Derveer of Somerville (1828-1885), a surgeon with the Fifth New Jersey Volunteers, described the work of a battlefield surgeon in a remarkable series of letters to his wife, Mary Squier. Rutgers also holds his field surgeon's instrument case, pictured in Steven Glazer's article. Another perspective on the war's medical history is offered by the diary of Alfred H. Buck, sergeant in Company H of the Twelfth New Jersey Volunteers. Wounded early in the battle of 
Gettysburg, Buck spent three months in the "Ward" U.S. General Hospital in Newark, an experience carefully recorded in his journal. So far these medical collections have been little used by researchers. The recent merger of the University of Medicine and Dentistry of New Jersey with Rutgers will encourage collaboration with the Special Collections in the History of Medicine at the George F. Smith Library, which also holds Civil War-related material, fostering further research in this area.

SC/UA's Civil War collections also include a wealth of civilian letters and diaries, many written by women. In the introduction to her edited collection The War

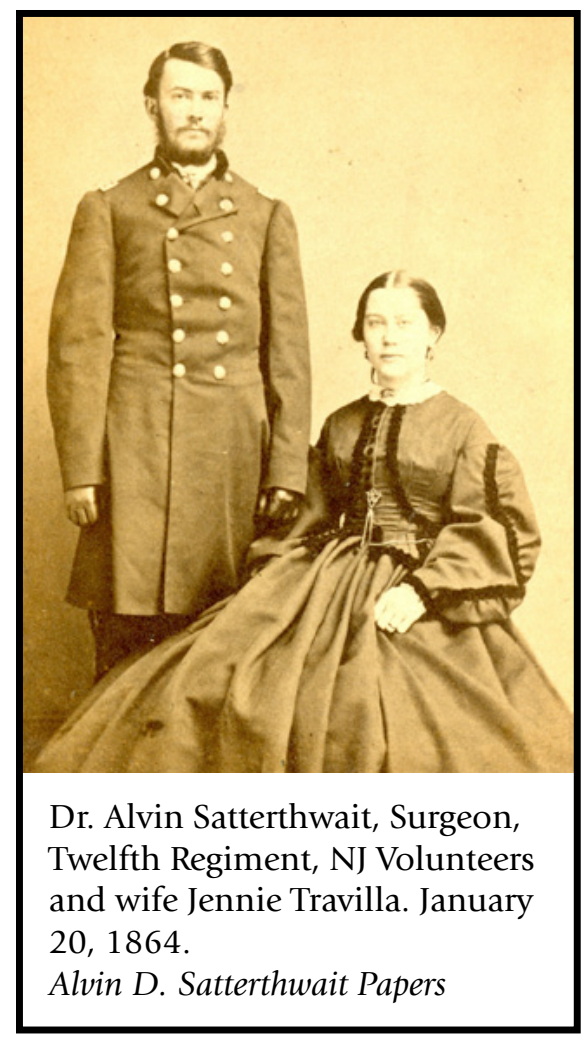
Was You and Me (2002), Joan

E. Cashin comments on the need for more research on the civilian experience of the North during the Civil War. Although the war did not devastate the Northern landscape as it did in the South, civilian lives were deeply affected. The war strained family relationships, destabilized gender roles, and challenged attitudes towards race. ${ }^{7}$ This experience can only be understood through local studies that take into account differences in region, race, class, religion, and ethnicity. Cashin's work on draft resistance in Ohio, Indiana, and Pennsylvania, and William Blair's research on recruiting in Pennsylvania are applicable to the New Jersey context, where recruiters struggled to fill quotas. ${ }^{8} \mathrm{SC} / \mathrm{UA}$ 's collections document the home front throughout the state of New Jersey-north and south, east and west, urban and rural. Included are the experiences of immigrants and ethnic groups, particularly German Americans, although those of Irish and African Americans are more elusive. Authors of diaries, letters, and documents come from a wide variety of social backgrounds ranging from landowners and politicians to 
the barely-literate families of enlisted men. Further mining of these sources will yield rich detail about the life of New Jerseyans during this unique and dramatic period.

\section{New Jersey Women and the Civil War}

The need to better understand the civilian experience in the North is one of the ways that the study of New Jersey women and the Civil War is important and necessary. Insights into women and gender have the potential to change our traditional picture of the military and political narrative of the war. During the war, women took on new public roles as nurses in relief organizations, in clerical positions, in factories, and in maintaining farms and businesses in the absence of fathers, husbands, sons, and brothers. Historians influenced by second-wave feminism have argued that these new roles had a radicalizing effect on women, laying the groundwork for the women's suffrage movement of the latter half of the nineteenth century. ${ }^{9}$ In subsequent years, historians have taken a more nuanced view, pointing out that women's experience of the Civil War differed widely according to race, class, ethnicity, and region. ${ }^{10}$ This "new gender history" centers women and gender relationships in the historical narrative. For instance, historian Elizabeth Varon has shown that the opposition to women's public role in the abolition movement polarized antebellum opinion, contributing to the perception that the differences between North and South were irreconcilable. By placing gender at the center of her analysis of the abolitionist movement, Varon offers a fresh approach to our understanding of the causes of the Civil War. ${ }^{11}$ In Daughters of the Union, Nina Silber synthesizes much of this recent scholarship. She states that the war transformed women's lives in the North, bringing them into a new relationship with a broad spectrum of economic, political, and military activities. Women were forced to interact with the nation-state in many new ways, including military pension programs and various forms of government employment. Through this process, women were made more clearly aware of their second-class status outside of the domestic realm. For example, women working in factories were paid less than men, while AfricanAmerican women whose husbands joined the military initially did not get pensions at all. ${ }^{12}$

The experience of New Jersey women and the Civil War stands out as an area that has been little explored by historians. Major academic studies of Northern women and gender during the Civil 
War have included little about New Jersey women and have not used New Jersey sources. ${ }^{13}$ There are almost no books, dissertations, or articles that focus exclusively on New Jersey women and the Civil War. Most of the work that has been done is in the form of local histories, encyclopedia entries, and classroom materials. For example, the New Jersey Civil War Heritage Association's New Jersey Goes to War includes eleven women who had some connection to New Jersey out of 150 biographical sketches, while New Jersey's Civil War Odyssey contains five accounts of women. Scores of other New Jersey women who made contributions large and small to the war effort can be located by delving through collections of local historical societies and genealogical resources. For example, the indexes to Donald A. Sinclair's A Guide to Civil War Manuscripts contain 514 references to women in Rutgers' collections. The experience of New Jersey women during the Civil War in relief organizations, as nurses on the battlefield and in hospitals, and as civilians will be reviewed below. As part of the discussion, attention will be drawn to resources at SC/UA and elsewhere that have yet to be fully mined by researchers.

\section{War Relief}

Probably the most common way that New Jersey women interacted with the public sphere during the Civil War was through relief work. When war broke out, New Jersey women quickly mobilized, raising money, collecting food, clothing, sheets, and blankets to ship to the troops. Local organizations sprang up all over the state. The United States Sanitary Commission (USSC), founded in 1861 to provide medical care, supplies, and other necessities to troops in the field, served as an umbrella agency for local relief groups. Branches of the Sanitary Commission were founded in New York, Philadelphia, Boston, Chicago, and other major cities. ${ }^{14}$ Women in northern New Jersey reported to the Women's Central Association for Relief (WCAR), which served as the New York branch of the Sanitary Aid Commission, while women in southern New Jersey reported to the Philadelphia branch. In November 1862, branch managers met in Washington and decided to adopt a system of associate managers in geographically-significant cities and towns to work with the branch managers. From 1862 to 1864, Eliza Powers, known as the Florence Nightingale of Paterson, served as associate manager of the U.S. Sanitary Commission of New Jersey. During this period, 
she collected over $\$ 8,000$ and 20,000 articles for hospital use including clothing, blankets, bandages, and many other items. More than sixty years old when she began her service, she accepted no remuneration for her work. ${ }^{15}$ Women also supported the work of the United States Christian Commission through founding auxiliaries in their churches to collect supplies and raise money for the war effort. ${ }^{16}$ Many of the entries in Sinclair's Civil War Manuscripts refer to women organizing to provide relief to soldiersknitting socks, making flags, and preparing needle books for new recruits among other activities.

Jeanie Attie's study of the WCAR, Patriotic Toil, reveals New Jersey women's struggles to mobilize for the war effort as well as tensions between local associations and the parent body. Isabella Stevens, of the prominent Hoboken family, noted that the Hoboken society never sent boxes to the USSC for central distribution; rather she brought them herself to government hospitals. ${ }^{17}$ In her report on a survey of local organizations, New York branch manager Louisa Lee Schuyler wrote "most women understand the federal principle (though more did so in New York, Massachusetts, and Vermont than in Connecticut and New Jersey)."18 The secretary of the Newark society wrote "in relation to the state of the feelings in this community in regard to the Sanitary Commission, I cannot say much that is favorable. ${ }^{\prime 19}$ Attie's study also exposes the inadequacy of generalizations about women's relief work, which was actually divided by race, class, and ethnicity, in New Jersey and elsewhere. By 1863, Stevens lamented that the Hoboken society was in abeyance, noting "the great preponderance of foreigners in the city." ${ }^{20}$ The head of a Paterson branch apologized that the society only raised about \$33 each month: "the amount may seem small to you but this city is a manufacturing one and we have few wealthy people." 21

Beginning in 1862, the Sanitary Commission operated a primitive ambulance system using government-owned river steamers to remove sick and wounded soldiers from the Virginia peninsula and transport them to Northern hospitals for treatment. Women, including many from prominent families, served as nurses on these hospital ships. ${ }^{22}$ One of these women was Christine Kean Griffin (1825-1915). Born into a prominent New Jersey family, Christine A.W. Kean grew up in Liberty Hall in Union, now the Kean University Museum. At the age of twenty-three, she married Captain William Preston Griffin, an officer in the U.S. Navy. Tragically, her young husband died in 1851, leaving Christine Kean 
Griffin a childless widow. When the Civil War broke out, Griffin volunteered for the USSC, serving as a nurse on hospital ships and other medical facilities. After the war, she became a philanthropist, devoting herself to wounded veterans, the Red Cross, and the new discipline of public health. Griffin became president of the board of managers of the nurses of New York's Bellevue Hospital, and is credited with designing the basic nurses' cap. $^{23}$

\section{Nursing}

In reality, the USSC only supplied a limited number of nurses to the war effort. Most Civil War women nurses were unaffiliated with any organization. New Jersey women, including several famous figures who happened to have a New Jersey connection, were well-represented among these volunteers. Born in Hampden, Maine, Dorothea Lynde Dix (1802-1887) became an advocate for the treatment and institutionalization of the mentally ill, resulting in the establishment of hospitals and asylums throughout the United States. When the Civil War broke out, Dix was staying with the

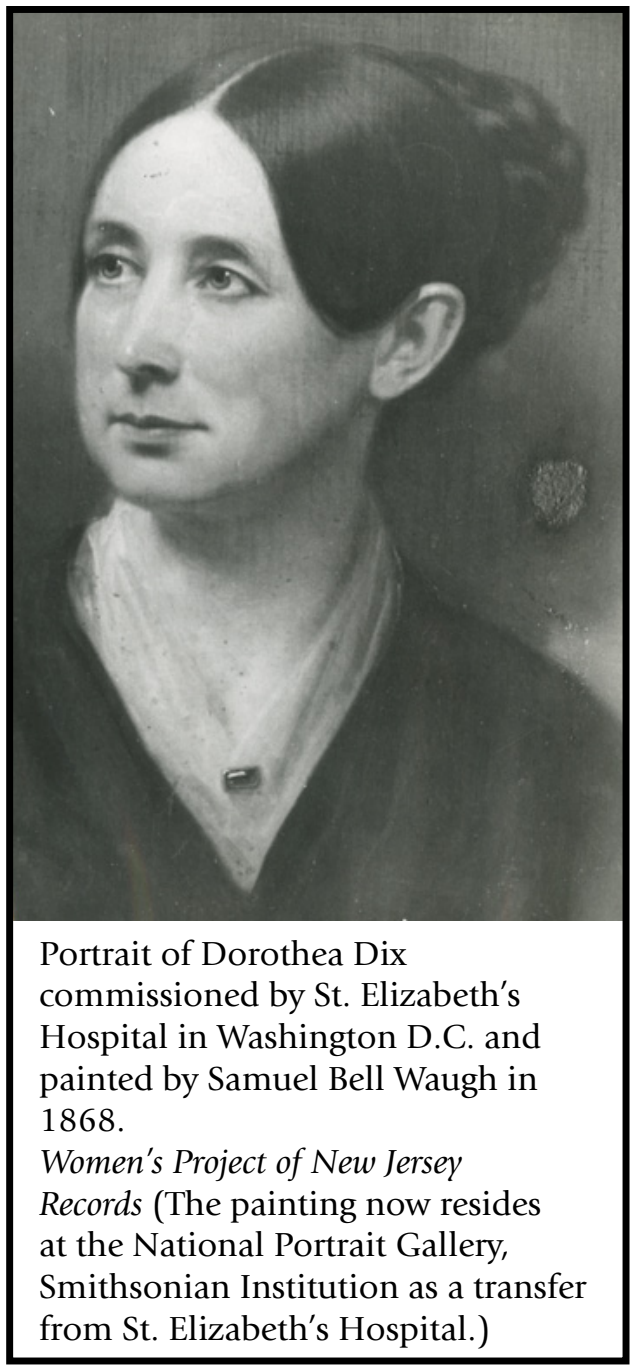
superintendent of the New

Jersey State Lunatic Asylum in Trenton (later the Trenton Psychiatric Hospital). Based on her knowledge of nursing at psychiatric hospitals and her study of Florence Nightingale's methods, she rushed to Washington to offer her services to President Lincoln. 
She was appointed Superintendent of Women Nurses for the Union army. ${ }^{24}$ After a rather troubled Civil War career, Dix would end her days living in a private suite in the Trenton hospital designated for her own use by the New Jersey legislature. Like Dix, Clara Barton (1821-1912) was a New Englander with New Jersey ties who heeded Lincoln's call to volunteer for the Union cause. Before the war, Barton had taught school in Hightstown, New Jersey, and founded one of the state's first free public schools in Bordentown. When the war began, Barton was working as a clerk in the U.S. Patent Office in Washington, D.C. Named the "angel of the battlefield," Barton volunteered as an unaffiliated nurse at the battles of Bull Run, Chantilly, and many others, helping to overcome the prejudice against women nurses on the battlefield. After the war, Barton labored for four years helping to identify missing soldiers, and later founded the American branch of the International Red Cross, serving as its first president. ${ }^{25}$

Although both Dix and Barton had a connection with the state, New Jersey-born and bred Cornelia Hancock (1840-1927) is probably the most famous New Jersey woman associated with the Civil War. Hancock was a Quaker and an abolitionist from Hancock's Bridge in Salem County. She determined to volunteer as a nurse upon hearing of the horrors of the Battle of Gettysburg. She accompanied her brother-in-law, Philadelphia abolitionist Dr. Henry T. Child and a party of older women on the train for Gettysburg. In Baltimore, Hancock met Dorothea Dix, who was vetting nurses for military service. "She looked the nurses over and pronounced them all suitable except me. She immediately objected to my going farther on the score of my youth and rosy cheeks. I was then just twenty-three years of age." ${ }^{26}$ While they were arguing, the train left. Hancock, who had remained on the train, proceeded to Gettysburg on her own.

Hancock spent the winter of 1863-64 nursing displaced African Americans at the Contraband Hospital in Washington, D.C. For the remainder of the war, she nursed at various front line hospitals including those in Brandy Station and City Point, Virginia. During Reconstruction, Hancock founded a school for newly-freed African Americans in South Carolina. ${ }^{27}$ Cornelia Hancock's Civil War letters were first edited by Henrietta S. Jaquette and published in 1937 as South after Gettysburg; and later reprinted with a new introduction as Letters of a Civil War Nurse (Lincoln, NE: University of Nebraska Press, 1998). The original letters are in the Cornelia 
Hancock Papers at the William L. Clement Library at the University of Michigan. No contemporary biography of Hancock exists, however.

Other women include Arabella W. Barlow (1824-1864) of Somerville, who enlisted as a nurse to stay close to her young husband, serving in the Peninsula, Antietam, and Gettysburg campaigns. At Gettysburg, Barlow crossed enemy lines to search for her wounded husband, and stayed with him to nurse him back to health. She ultimately contracted typhus and died of the disease in $1864 .{ }^{28}$ Similarly, Frances "Fanny" Ricketts (1834-1900) of Elizabeth crossed Confederate lines to nurse her critically-wounded and captured husband and other soldiers after the First Battle of Bull Run, successfully preventing the amputation of his leg. After her husband's recovery, she refused to leave him and was interned with him at Libby Prison, where she helped gain his freedom through a prisoner exchange. ${ }^{29}$ The women discussed above were almost all middle-class, Protestant, white women. In reality, Civil War nurses were divided by class, race, and religion. In her study of women hospital workers, Jane E. Schultz debunks the myth that the majority of nurses were white and middle-class. ${ }^{30}$ Her research is based on pension records of nurses at the National Archives, records that could potentially be mined to find New Jersey women.

In order to escape crowded and unsanitary battlefield hospitals, soldiers were shipped to home front hospitals where they could receive better care. In Newark, businessman and later governor Marcus L. Ward opened "Ward's" U.S. General Hospital in May 1862. By the time the hospital was decommissioned in 1865, about 80,000 military patients had been treated. SC/UA holds documentation of the hospital in the Marcus Ward Papers. Particularly early in the war, Northern women confronted opposition to serving as nurses at military hospitals. Many nurses were convalescing soldiers. ${ }^{31}$ At Ward's Hospital, many women served as laundresses and domestic workers. In-depth study of diaries and letters may yield more information about Newark's Civil War nurses.

Several hundred members of Roman Catholic women's religious communities served as nurses during the Civil War. ${ }^{32}$ Although it is unlikely that any sisters from New Jersey were among the nuns who served on the battlefield, Catholic sisters nursed New Jersey soldiers in one of the first home front hospitals and first Catholic hospitals in the state during the Civil War. The Franciscan 
Sisters of the Poor, a nursing order founded in Germany in 1845 , came to the United States in 1859. The sisters settled in Cincinnati, Ohio, where they opened a hospital that treated wounded soldiers from the Western theater of war. In January 1863, Mrs. Sarah Peter, a supporter of the sisters in Cincinnati, traveled to New Jersey, where she spoke to the Reverend Anthony Couven, pastor of St. Mary's Church in Hoboken about the need to better care for wounded soldiers. A small house was rented at 324 Park Avenue for the sisters, who began visiting patients, nursing, and caring for orphaned and abandoned children, some of whom were probably the children of soldiers. Later that year, the sisters purchased a new site for the hospital at Fourth Street and Willow Avenue in Hoboken; construction of what became St. Mary's Hospital began in $1866 .{ }^{33}$ The origins of Catholic health care in New Jersey can thus be tied to this little-known story of women's work as nurses during the Civil War.

\section{Women Soldiers}

Nurses were not the only women who found their way to the battlefields of the Civil War. In their studies of women who fought in the Civil War, Dee Ann Blanton and Richard H. Hall both document several New Jersey women among those who disguised themselves as men to take part in the military conflict. These studies help destabilize the traditional gendered dichotomy of men on the battlefield/women on the home front. Blanton recounts the fascinating story of an unidentified New Jersey woman who took part in the Seven Days battles, was wounded at Antietam, and promoted to corporal at Fredericksburg. In January 1863, she gave birth to a healthy baby boy, "who became the subject of much gossip in the Army of the Potomac." ${ }^{34}$ Many stories were told about this unnamed woman, the details of whose movements remain sketchy. Based on a pension application, Elizabeth Leonard identifies another New Jersey woman, Emma A. B. Kinsey, as serving as a lieutenant colonel with the Fortieth New Jersey regiment. ${ }^{35}$ Joseph Bilby's evidence shows, however, that in July 1865, while the Fortieth New Jersey was stationed in Washington, D.C. waiting to be discharged from federal service, Kinsey's husband John Warner Kinsey arranged for Colonel J. Augustus Fay to draw up papers promoting his wife to brevet lieutenant colonel. ${ }^{36}$ The Kinsey family papers are located at the National Guard Militia Museum in Sea Girt, New Jersey. 


\section{Women Writers}

The political rhetoric of the war years was highly gendered. At a time when women did not have direct access to the political machinery, they were able to find a voice through writing and making speeches. ${ }^{37}$ Donald Sinclair's A Bibliography: The Civil War and New Jersey (1968) includes numerous examples of women's published writings during the Civil War era in books, pamphlets, broadsides, and magazines. Study of New Jersey's vibrant newspaper culture of the Civil War period would most likely yield many more examples of women's writing. Cultural historians have focused on how gender relations have been expressed through women's (and men's) literary and artistic production during the Civil War. In some cases, the Civil War became a launching pad for female authors. ${ }^{38}$ One of these women was poet Ellen Clementine Howarth (18271899) of Trenton. Born Ellen Doran, the daughter of a calico-printer in Cooperstown, New York, Howarth settled in Trenton after her marriage where she helped support the family by caning chairs. She reputedly composed her poems while doing housework. Her poems were originally published in newspapers in Trenton under the name "Clementine" and later in magazines. Her first book of collected poetry, The Wind Harp, and Other Poems (1864) included several poems about patriotism, war, and the death of loved ones. She also wrote a number of songs, including "Tis but a Little Faded Flower." Her later work Poems was edited by Richard Watson Gilder. ${ }^{39}$

\section{Women Civilians}

Finally, one of the most important ways that research on New Jersey women can contribute to the understanding of the role of gender during the Civil War is through the study of women on the home front. How did civilian women's activities help or perhaps hinder the Union cause? Does the stereotype of brave ladies on the home front supporting the troops hold up? In Army at Home: Women and the Civil War on the Northern Home Front, Judith Giesberg unsettles the wartime image of women standing still in anticipation of the return of husbands, sons, and brothers. Looking at marginal rural Northern women, she proposes an alternative wartime geography where women left home to find work or apply for aid, or traveled to urban hospitals and Southern battlefields to find loved ones. Her study, which includes black, white, and immigrant women, blurs the boundaries of time and space, home front, and war front. Giesberg looks primarily at Massachusetts and Pennsylvania, as well 
as New York, San Francisco, and Washington, D.C., but anticipates that her book will lead to comparative studies. ${ }^{40}$

While several studies exist of civilian women in neighboring Pennsylvania, no major studies have yet been done on civilian women in New Jersey during the Civil War. ${ }^{41}$ Giesberg's book is primarily based on applications for relief, an approach which could also be used for New Jersey. For example, the database of Civil War Payment Vouchers held by the New Jersey State Archives can be searched to find information about women who applied for support from the state during and after the Civil War. ${ }^{42}$

SC/UA's manuscript collections include rich documentation of civilian women in New Jersey. In their wartime letters, women discuss their opinions about the war-political developments, bounties, hiring substitutes, and the draft. The writers range from upper-middle class rural women like Mary Ellen Hoagland Voorhees of Six Mile Run in Somerset County to urban women like Judith Gile, an unmarried Newark woman whose diary is held by SC/UA, to the working-class correspondents of Henrietta Boice of Bound Brook found in the Charles Philhower Collection. Family relationships are revealed by letters between couples, such as Enoch Brooks, a private in the Third New Jersey Calvary and his wife Elizabeth; and Enoch Lloyd Coward, quartermaster of the Fourteenth New Jersey and his wife Anna, twenty-five of whose letters are in the collection. A broadside printed by the Newark Daily Mercury calls attention to the destitute condition of families left behind by soldiers. ${ }^{43}$ The Peter A. Voorhees Collection documents payments to wives and widows of soldiers in Somerset County, many of whom could only sign with an " $x$ ". Most telling are the records of Marcus L. Ward's "Office for Soldiers' Business," which helped soldiers, veterans, and their families with health, welfare, and obtaining pensions. Most of the applicants were wives, widows, and orphaned children of Newark men, including many immigrants from Germany and Ireland.

This brief essay has only touched on a few areas that can be fruitfully pursued as dissertation topics or subjects for books and articles. The aftermath of the Civil War in New Jersey and the subsequent construction of the war in the state's memory are likewise ripe subjects for future scholars. Only when detailed local studies have been completed can a true picture of the Civil War in the North be created. I hope that this special issue of the Journal of the Rutgers University Libraries will begin that conversation and inspire others to continue it. 
Notes

1. Joseph G. Bilby, "New Jersey in the Civil War," New Jersey Civil War 150 Committee, 2014 http://www.njcivilwar150.org/njinthecw.htm.

2. See William J. Jackson, New Jerseyans in the Civil War: For Union and Liberty (New Brunswick, NJ: Rutgers University Press, 2000); Joseph G. Bilby and William C. Goble, "Remember You Are Jerseymen": A Military History of New Jersey's Troops in the Civil War (Hightstown, NJ: Longstreet House, 1998); and William Gillette, Jersey Blue: Civil War Politics in New Jersey, 1854-1865 (New Brunswick, NJ: Rutgers University Press, 1995).

3. Alan A. Siegel, For the Glory of the Union: Myth, Reality, and the Media in Civil War New Jersey (Rutherford, NJ: Fairleigh Dickinson University Press, 1984) and Alan A. Siegel, Beneath the Starry Flag: New Jersey's Civil War Experience (New Brunswick, NJ: Rutgers University Press, 2001).

4. Examples of regimental histories include Bradley M. Gottfried, Kearny's Own: The History of the First New Jersey Brigade in the Civil War (New Brunswick, NJ: Rutgers University Press, 2005); and John G. Zinn, The Mutinous Regiment: The Thirty-third New Jersey in the Civil War (Jefferson, NC: McFarlane and Co., 2005) and Bernard A. Olsen, ed., Upon the Tented Field: An Historical Account of the Civil War as Told by the Men Who Fought and Gave Their Lives (Red Bank, NJ: Historic Projects, Inc., 1993); local histories include Joanne Hamilton Rajoppi, New Brunswick and the Civil War: The Brunswick Boys in the Great Rebellion (Charleston, SC: The History Press, 2013); Joseph G. Bilby focuses on the experience of African-Americans in "Freedom to All": New Jersey's African-American Civil War Soldiers. (Hightstown, NJ: Longstreet House, 2011).

5. Joseph G. Bilby, ed., New Jersey's Civil War Odyssey: An Anthology of Civil War Tales from 1850 to 1961 (Hightstown, NJ: New Jersey Civil War Heritage Association, 2011) and Joseph G. Bilby, ed., New Jersey Goes to War: Biographies of 150 New Jerseyans Caught Up in the Struggle of the Civil War, Including Soldiers, Civilians, Men, Women, Heroes, Scoundrels-and a Heroic Horse (Hightstown, NJ: New Jersey Civil War Heritage Association, 2010).

6. Eric T. Dean, Shook Over Hell: Post-Traumatic Stress Disorder, Vietnam, and the Civil War (Cambridge, MA: Harvard University Press, 1997) and Lisa A. Long, Rehabilitating Bodies: Health, History, and the American Civil War (Philadelphia, PA: University of Pennsylvania Press, 2004).

7. Joan E. Cashin, ed., The War Was You and Me: Civilians in the American Civil War (Princeton, NJ: Princeton University Press, 2002), $1-3$. 
8. Joan E. Cashin, "Deserters, Civilians, and Draft Resistance in the North," and William Blair, "We Are Coming, Father AbrahamEventually: The Problem of Northern Nationalism in the Pennsylvania Recruiting Drives of 1862," in Cashin, ed., The War Was You and Me.

9. See for example, Mary Elizabeth Massey, Bonnet Brigades (New York: Knopf, 1966) and more recently Marilyn Culpepper, Trials and Triumphs: The Women of the American Civil War (East Lansing, MI: Michigan State University, 1991).

10. See for example, Ella Forbes, African American Women during the Civil War (New York: Garland Publishing, 1998).

11. Elizabeth R. Varon, "Gender History and the Origins of the Civil War," OAH Magazine of History 25, no. 2 (2011): 19-23.

12. Nina Silber, Daughters of the Union: Northern Women Fight the Civil War (Cambridge, MA: Harvard University Press, 2005), 9-12 and 61-64.

13. For example, Catherine Clinton and Nina Silber, ed., Battle Scars: Gender and Sexuality in the American Civil War (New York: Oxford University Press, 2006); Judith Ann Giesberg, Army at Home: Women and the Civil War on the Northern Home Front (Chapel Hill, NC: University of North Carolina Press, 2009); Elizabeth D. Leonard, Yankee Women: Gender Battles and the Civil War (New York: W. Norton, 1994); Jane E. Schultz, Women at the Front: Hospital Workers in Civil War America (Chapel Hill, NC: University of North Carolina Press, 2004); Nina Silber, Daughters of the Union: Northern Women Fight the Civil War (Cambridge, MA: Harvard University Press, 2005); and Lyde Cullen Sizer, The Political Work of Northern Women Writers and the Civil War, 1850-1872 (Chapel Hill, NC: University of North Carolina Press, 2000).

14. Judith Ann Giesberg, Civil War Sisterhood: The U.S. Sanitary Commission and Women's Politics in Transition (Boston, MA: Northeastern University Press, 2000), 12.

15. Edward M. Graf, "Eliza Howard Powers," 1935, The Passaic County History Society, 2000-2009 www.lambertcastle.org/powers.html. See also The Messenger of the United States Sanitary Commission for New Jersey Newark, NJ: U.S. Sanitary Commission, (1864).

16. David A. Raney, "In the Lord's Army: The United States Christian Commission in the Civil War" (Ph.D. diss., University of Illinois, Urbana-Champaign, 2001), 36-37.

17. Jeanie Attie, Patriotic Toil: Northern Women and the American Civil War (Ithaca, NY: Cornell University Press, 1998), 105.

18. Ibid., 151-152.

19. Ibid., 139.

20. Quoted in Attie, 222.

21. Attie, 136. 
22. Giesberg, Civil War Sisterhood, 114-119.

23. "Christine A. W. Kean Griffin," available at http://www.kean.edu/ libertyhall/TeachersResource/pdf/lesson plans/WomensHistory MS.pdf.

24. See for example, Thomas J. Brown, Dorothea Dix: New England Reformer (Cambridge, MA: Harvard University Press, 1998), David Gollaher, Voice for the Mad: The Life of Dorothea Dix (New York: Free Press, 1995), and Frederick M. Herrmann, Dorothea L. Dix and the Politics of Institutional Reform (Trenton, NJ: New Jersey Historical Commission, 1981).

25. See Stephen B. Oates, A Woman of Valor: Clara Barton and the Civil War (Toronto, ON: Maxwell Macmillan Canada, 1994) and Elizabeth Brown Pryor, Clara Barton: Professional Angel (Philadelphia, PA: University of Pennsylvania Press, 1987).

26. Henrietta Stratton Jaquette, ed., South after Gettysburg: Letters of Cornelia Hancock from the Army of the Potomac, 1863-1865 (Philadelphia, PA: University of Pennsylvania Press, 1937), 3.

27. Bilby, New Jersey Goes to War, 60.

28. "Arabella W. Barlow," New Jersey Women's History, 2014. Available at www.njwomenshistory.org/discover/biographies/arabella-wbarlow and New Jersey Goes to War, 5.

29. Karen Kinzey, "Fanny Ricketts," in Lisa Tendrich Frank, ed., Women in the American Civil War (Santa Barbara, CA: ABC-CLIO, 2008); and Bilby, New Jersey Goes to War, 107.

30. Schultz, 5 .

31. Ibid., 53-55.

32. See Sister Mary Denis Maher, To Bind Up the Wounds: Catholic Sister Nurses in the U.S. Civil War (New York: Greenwood Press, 1989).

33. Franciscan Sisters of the Poor Centenary Souvenir, 1845-1945. ADN 12.0, Religious Orders of Women Collection, Box 4, Monsignor Noé Field Special Collections, Seton Hall University Libraries. In 2014, this hospital is known as CarePoint Hoboken University Medical Center.

34. Dee Ann Blanton and Lauren M. Cook, They Fought Like Demons: Women Soldiers in the American Civil War (Baton Rouge, LA: Louisiana State University Press, 2002), 13-15.

35. Elizabeth D. Leonard, All the Daring of the Soldier: Women of the Civil War Armies (New York: W. W. Norton, 1999), 206-207. Richard H. Hall also identifies Kinsey in Women on the Civil War Battlefront (Lawrence, KS: University of Kansas, 2006), 245.

36. Bilby, New Jersey's Civil War Odyssey, 96-97. Bilby identifies her as Emily Buzby Kinsey.

37. Clinton and Silber, 14-15.

38. Ibid., 4-12. 
39. Bilby, New Jersey Goes to War, 69.

40. Giesberg, Army at Home, 9-15.

41. See for example, Rachel Seidman, "Beyond Sacrifice: Women and Politics on the Pennsylvania Home Front during the Civil War" (unpublished Ph.D. Dissertation, Yale University, 1991) and Judith Ann Giesberg, "From Harvest Field to Battlefield: Rural Pennsylvania Women and the U.S. Civil War," Pennsylvania History 72, no. 2 (Spring 2005): 159-191.

42. Civil War Payment Vouchers, 1861-1865, 2013. New Jersey State Archives https://wwwnet1.state.nj.us/DOS/Admin/ArchivesDBPortal/ CivilWarVouchers.aspx (visited June 1, 2014).

43. The Families of Volunteers [Newark, NJ, 1861] New Jersey Broadsides Collection, Special Collections and University Archives, Rutgers University Libraries. 